\title{
Les Epistres des dames de Grece. Une version médiévale en prose française des "Héroides" d'Ovide, éditée par Luca Barbieri
}

\section{Barbara Ferrari}

\section{(2) OpenEdition}

\section{Journals}

Édition électronique

URL : http://journals.openedition.org/studifrancesi/7820

DOI : 10.4000/studifrancesi.7820

ISSN : 2421-5856

Éditeur

Rosenberg \& Sellier

\section{Édition imprimée}

Date de publication : 1 juillet 2009

Pagination : 369

ISSN : 0039-2944

\section{Référence électronique}

Barbara Ferrari, «Les Epistres des dames de Grece. Une version médiévale en prose française des "Héroides" d'Ovide, éditée par Luca Barbieri », Studi Francesi [En ligne], 158 (LIII | II) | 2009, mis en ligne le 30 novembre 2015, consulté le 12 janvier 2021. URL : http://journals.openedition.org/studifrancesi/ 7820 ; DOI : https://doi.org/10.4000/studifrancesi.7820

Ce document a été généré automatiquement le 12 janvier 2021.

\section{cc) $(9)$}

Studi Francesi è distribuita con Licenza Creative Commons Attribuzione - Non commerciale - Non opere derivate 4.0 Internazionale. 


\title{
Les Epistres des dames de Grece. Une version médiévale en prose française des "Héroides" d'Ovide, éditée par Luca Barbieri
}

\author{
Barbara Ferrari
}

\section{RÉFÉRENCE}

Les Epistres des dames de Grece. Une version médiévale en prose française des "Héroides" d'Ovide, éditée par Luca BARBIERI, Paris, Champion, 2007 («Classiques français du Moyen Âge», 152), pp. 212.

1 L. Barbieri présente ici une version abrégée et en français de son importante monographie parue en 2005 dans la collection «Romanica Helvetica»: Le "epistole delle dame di Grecia" nel "Roman de Troie" in prosa. La prima traduzione francese delle "Eroidi" di Ovidio (Tübingen, Francke, 2005; cf. SF, 157, pp. 149-150). Quelques chapitres de l'editio longior ont été sacrifiés ou abrégés, mais le lecteur dispose de l'essentiel de l'information et le résultat est d'une grande qualité.

2 La première traduction française, partielle, des Héroïdes ovidiennes comprend treize épîtres transmises à l'intérieur de la version en prose du Roman de Troie dite Prose 5, qui a circulé dans la vaste compilation connue sous le nom d'Histoire ancienne jusqu'à César. L'édition des épîtres, richement annotée (pp. 73-179, avec quelques menues corrections au texte donné en 2005), est précédée d'une Introduction (pp. 7-72) présentant les 19 mss. qui nous ont transmis les textes, presque tous produits en France au cours $\mathrm{du}_{\mathrm{xv}}^{\mathrm{e}}$ siècle. Le ms. Royal 20.D.I de la British Library de Londres, réalisé à Naples en milieu angevin vers $1330-40$ est à l'origine de toute la tradition manuscrite, «rare cas de conservation du niveau archétypique» (p. 16), et son texte est par conséquent adopté comme base pour l'édition. Le paragraphe intitulé «L'histoire du texte» (pp. 18-28) est 
consacré au contexte de transmission des épîtres: Prose 5, rédigée dans le même milieu, est caractérisée par la pluralité des sources mises à profit et par le ton élégiaque et lyrique; parmi les insertions opérées par l'auteur, la plus importante est sans aucun doute celle des treize Héroïdes. Ces dernières ont connu vraisemblablement une circulation indépendante, comme le prouve le ms. italien Gaddi reliqui 71 de la Laurentienne de Florence (première moitié du XIV s.), qui contient la traduction en italien d'une autre version du Roman de Troie, l'Istorietta troiana (trad. de Prose 3), et de quatre épîtres translatees à partir du même modèle français du ms. Royal. Les Héroïdes du ms. Gaddi présentent un texte plus complet, ce qui prouve que l'auteur de Prose 5 ne peut pas être le traducteur des épîtres ovidiennes. Deux autres paragraphes présentent efficacement «Le style des Héroïdes françaises» (pp. 29-35) et «La langue des Héroïdes dans le ms. Royal 20.D.I» (pp. 35-56; certaines parties, p. ex. la section lexicale, sont même plus riches que dans le volume de 2005). Une Bibliographie définie sommaire occupe néanmoins les pp. de 57 à 72 . Le texte est accompagné d'un «Index des noms propres» (pp. 181-188) et d'un «Glossaire» (pp. 189-210) un peu plus riche que celui de l'édition 2005 (deux items ajoutés: damoise et ostesse). 